\title{
PENGETAHUAN, SIKAP DAN PERSONAL HYGIENE TENAGA PENJAMAH MAKANAN DI RUANG PENGOLAHAN MAKANAN
}

\author{
Amalia Safitri Assidiqi ${ }^{1 *}$, Made Darawati ${ }^{1}$, AASP Chandradewi ${ }^{1}$ dan Ni Luh Suranadi ${ }^{1}$ \\ ${ }^{1}$ Jurusan Gizi, Poltekkes Kemenkes Mataram, Indonesia \\ Jalan Praburangkasari Dasan Cermen, Sandubaya Kota Mataram \\ Telp./Fax. (0370) 633837, \\ Email : amaliasafitri.a1@gmail.com
}

\begin{tabular}{l} 
Article Info \\
\hline Article history: \\
Received July $16^{\text {th }}, 2019$ \\
Revised August $25^{\text {th }}, 2019$ \\
Accepted September $27^{\text {th }}, 2019$ \\
Keyword: \\
Application of Personal \\
Hygiene; Attitude; Food \\
Handlers and Processing \\
Room; Knowledg
\end{tabular}

\begin{abstract}
Background. According to Fatmawati, et al. (2013), one of the basic principles of organizing institutional food is the organization of foods that implement hygiene and sanitation in accordance with applicable regulations. One of the factors that support the principle of hygiene and sanitation in the provision of food is the factor of personal food hand hygiene. Personal hygiene is a clean, safe and healthy behavior of food handlers to prevent food contamination from food preparation to food serving. Some important procedures for food handlers, namely washing hands before and after handling food, using complete personal protective equipment and personal hygiene and health. This study aims to determine the description of knowledge, attitudes and personal hygiene of food handlers in the food processing room of the Tabanan General Hospital.
\end{abstract}

Research Methods. This type of research is observational descriptive and in terms of time, including the type of cross-sectional study. Data collection methods used were questionnaire and observation.

Research Result. The sample used was all food processing staff at the Nutrition Installation of the Tabanan General Hospital as many as 14 people. Most of the food processing staff were female (64\%), were in the age range between 30-49 years (79\%), the last education was secondary education (86\%) and had worked for more than 3 years (100\%). The average overall knowledge, attitude and application of personal hygiene of food handlers are included in both categories. Knowledge and attitudes of all food processing staff are included in the good category because ISO 9001: 2015 has been applied. Likewise, the application of personal hygiene before and after ISO 9001: 2015 shows that all food processing personnel apply personal hygiene well.

Copyright $\odot$ Jurnal Gizi Prima All rights reserved.

\section{PENDAHULUAN}

Makanan merupakan salah satu sumber penting untuk kelangsungan hidup manusia dan merupakan kebutuhan dasar manusia yang wajib dipenuhi guna menjaga kesehatan, meningkatkan kecerdasan dan produktivitas kerja. Oleh karena itu makanan yang berkualitas baik harus bergizi tinggi, mempunyai rasa yang lezat, menarik, bersih dan tidak membahayakan bagi tubuh, untuk itu diperlukan system penyelenggaraan yang baik (Wulandari, 2011).

Menurut Fatmawati, dkk. (2013), salah satu prinsip dasar penyelenggaraan makanan institusi adalah penyelenggaraan makanan yang menerapkan hygiene dan sanitasi sesuai ketentuan yang berlaku. Salah satu 
faktor yang mendukung prinsip hygiene dan sanitasi penyelenggaraan makanan adalah faktor kebersihan penjamah makanan atau hygiene perorangan. Hygiene perorangan merupakan perilaku bersih, aman dan sehat penjamah makanan untuk mencegah terjadinya kontaminasi pada makanan mulai dari persiapan bahan makanan sampai penyajian makanan. Beberapa prosedur penting bagi penjamah makanan, yaitu cuci tangan sebelum dan sesudah memegang bahan makanan, memakai alat pelindung diri yang lengkap dan kebersihan serta kesehatan diri.

Suatu penelitian di beberapa negara industry menunjukkan bahwa lebih dari $60 \%$ penyakit bawaan makanan atau foodborn disease disebabkan karena buruknya kemampuan penjamah makanan untuk mengolah makanan. Makanan yang tidak dikelola dengan baik dan benar oleh penjamah makanan dapat menimbulkan dampak negatif seperti penyakit dan keracunan akibat bahan kimia, mikroorganisme, tumbuhan atau hewan, serta dapat pula menimbulkan alergi (Fatmawati, 2013). Higiene perorangan yang terlibat dalam pengolahan makanan dapat dicapai apabila dalam diri pekerja tertanam pengertian tentang pentingnya menjaga kesehatan dan kebersihan diri.

Pada pengamatan yang dilakukan terhadap tenaga pengolah makanan di Instalasi Gizi Badan Rumah Sakit Umum Tabanan, masih ditemukan perilaku yang tidak sesuai dengan penerapan personal hygiene yaitu : pemakaian cincin saat mengolah makanan, tenaga pengolah makanan menutup luka dengan plester tidak kedap air, berbicara saat mengolah makanan dan membuka pasang masker selama proses pengolahan makanan.

Berdasarkan urairan latar belakang di atas maka telah dilakukan penelitian tentang "Gambaran Pengetahuan, Sikap dan Personal Hygiene Tenaga Penjamah Makanan Di Ruang Pengolahan Makanan Badan Rumah Sakit Umum Tabanan".

\section{METODE PENELITIAN}

Jenis penelitian ini adalah observasional deskriptif dan dari segi waktu termasuk jenis penelitian crossectional. Metode pengumpulan data yang digunakan yaitu kuesioner dan observasi. Sampel yang digunakan adalah seluruh tenaga pengolah makanan di Instalasi Gizi Badan Rumah Sakit Umum Tabanan sejumlah 14 orang.

\section{HASIL PENELITIAN}

Karakteristik Tenaga Penjamah Makanan Di Ruang Pengolahan Makanan

Tabel 1. Data Karakteristik Tenaga Penjamah Makanan Di Ruang Pengolahan Makanan

\begin{tabular}{cccccc}
\hline No & $\begin{array}{c}\text { Nama Tenaga } \\
\text { Pngolah Makanan }\end{array}$ & Jenis Kelamin & Umur (Tahun) & Pendidikan & Lama Bekerja \\
\hline 1. & Tn. WS & L & 26 & D1 Perhotelan & 4 \\
2. & Ny. SrA & P & 43 & SLTA & 10 \\
3. & Ny. SW & P & 37 & SLTA & 19 \\
4. & Tn. NS & L & 36 & SMK Boga & 9 \\
5. & Ny. NL & P & 36 & SLTA & 16 \\
6. & Ny. WE & P & 38 & SLTA & 15 \\
7. & Ny. NyK & P & 37 & SLTA & 17 \\
8. & Ny. NK & P & 45 & SLTA & 9 \\
9. & Ny. WM & P & 37 & SLTA & 17 \\
10. & Tn. WA & L & 43 & SMK & 17 \\
11. & Ny. NW & P & 42 & SLTA & 4 \\
12. & Ny. SA & P & 54 & SMK & 19 \\
13. & Tn. WR & L & 25 & SMK & 4 \\
14. & Tn. DG & L & 40 & D1 Boga & 9 \\
\hline
\end{tabular}


Tabel 2. Persentase Data Karakteristik Tenaga Penjamah Makanan Di Ruang Pengolahan Makanan

\begin{tabular}{|c|c|c|}
\hline Parameter & $\begin{array}{c}\text { Jumlah Tenaga } \\
\text { Pengolah Makanan }\end{array}$ & Persentase $(\%)$ \\
\hline \multicolumn{3}{|c|}{ Jenis Kelamin } \\
\hline Perempuan & 9 orang & $64 \%$ \\
\hline Laki-laki & 5 orang & $36 \%$ \\
\hline Total & 14 orang & $100 \%$ \\
\hline \multicolumn{3}{|c|}{ Umur } \\
\hline $15-29$ tahun & 2 orang & $14 \%$ \\
\hline 30-49 tahun & 11 orang & $79 \%$ \\
\hline 50-64 tahun & 1 orang & $7 \%$ \\
\hline Total & 14 orang & $100 \%$ \\
\hline \multicolumn{3}{|c|}{ Pendidikan } \\
\hline Pendidikan rendah (SD, MI, SMP dan MTs) & - & \\
\hline Pendidikan menengah (SMA, MA, SMK dan MAK) & 12 orang & $86 \%$ \\
\hline $\begin{array}{l}\text { Pendidikan tinggi (diploma, sarjana, magister, spesialis } \\
\text { dan doktor) }\end{array}$ & 2 orang & $14 \%$ \\
\hline $\begin{array}{l}\text { Total } \\
\end{array}$ & 14 orang & $100 \%$ \\
\hline \multicolumn{3}{|c|}{ Lama Bekerja } \\
\hline$<3$ tahun & - & - \\
\hline$\geq 3$ tahun & 14 orang & $100 \%$ \\
\hline Total & 14 orang & $100 \%$ \\
\hline
\end{tabular}

Berdasarkan Tabel 2 dapat diketahui bahwa sebagian besar tenaga pengolah makanan berjenis kelamin perempuan (64 \%), berada pada rentang usia antara 30-49 tahun (79\%), pendidikan terakhir adalah pendidikan menengah $(86 \%)$ dan telah bekerja lebih dari 3 tahun $(100 \%)$.

Tabel 3 Rata-Rata Skor Pengetahuan dan Sikap Tanaga Penjamah Makanan Di Ruang Pengolahan Makananan

\begin{tabular}{cccc}
\hline No & $\begin{array}{c}\text { Nama Tenaga Pngolah } \\
\text { Makanan }\end{array}$ & $\begin{array}{c}\text { Skor Pengetahuan } \\
(\boldsymbol{\%})\end{array}$ & $\begin{array}{c}\text { Skor Sikap } \\
(\boldsymbol{\%})\end{array}$ \\
\hline 1. & Tn. WS & 100 & 100 \\
2. & Ny. SrA & 100 & 100 \\
3. & Ny. SW & 100 & 100 \\
4. & Tn. NS & 100 & 100 \\
5. & Ny. NL & 100 & 100 \\
6. & Ny. WE & 100 & 100 \\
7. & Ny. NyK & 100 & 100 \\
8. & Ny. NK & 100 & 100 \\
9. & Ny. WM & 100 & 100 \\
10. & Tn. WA & 100 & 100 \\
11. & Ny. NW & 100 & 100 \\
12. & Ny. SA & 100 & 100 \\
13. & Tn. WR & 100 & 100 \\
14. & Tn. DG & 100 & 100 \\
\hline
\end{tabular}

Berdasarkan Tabel 3 dapat diketahui bahwa rata-rata keseluruhan pengetahuan dan sikap tenaga penjamah makanan termasuk dalam kategori baik. 
Data Skor Personal Hygiene Tenaga Penjamah Makanan Di Ruang Pengolahan Makanan

Di Instalasi Gizi Badan Rumah Sakit Umum Tabanan dilakukan penilaian akreditasi ISO 9001:2015 yang dilaksanakan selama 4 hari yaitu dari tanggal 23 April s/d 26 April 2019, sehingga pengamatan yang dilakukan terhadap penerapan personal hygiene dibedakan menjadi sebelum dan sesudah pelaksanaan ISO 9001:2015.

Rata-rata skor penerapan personal hygiene tenaga penjamah makanan sebelum dan sesudah dilakukan penilaian akreditasi ISO 9001:2015 disajikan pada Tabel 4.

Tabel 4. Rata-Rata Skor Penerapan Personal Hygiene Tenaga Penjamah Makanan Di Ruang Pengolahan

\begin{tabular}{cccc}
\hline \multirow{2}{*}{ No } & Nama Tenaga Pngolah & \multicolumn{2}{c}{ Skor Penerapan Hygiene (\%) } \\
& Makanan & Sebelum ISO & Sesudah ISO \\
\hline 1. & Tn. WS & 93 & 100 \\
2. & Ny. SrA & 100 & 100 \\
3. & Ny. SW & 93 & 100 \\
4. & Tn. NS & 93 & 100 \\
5. & Ny. NL & 100 & 100 \\
6. & Ny. WE & 100 & 100 \\
7. & Ny. NyK & 100 & 100 \\
8. & Ny. NK & 93 & 100 \\
9. & Ny. WM & 100 & 100 \\
10. & Tn. WA & 100 & 100 \\
11. & Ny. NW & 93 & 100 \\
12. & Ny. SA & 100 & 100 \\
13. & Tn. WR & 100 & 100 \\
14. & Tn. DG & 100 & 100 \\
\hline
\end{tabular}

Berdasarkan Tabel 4 dapat diketahui bahwa rata-rata keseluruhan penerapan personal hygiene tenaga penjamah makanan sebelum dan sesudah dilakukan penilaian akreditasi ISO 9001:2015 termasuk dalam kategori baik. Setelah penilaian tersebut terdapat peningkatan skor penerapan personal hygiene secara keseluruhan menjadi $100 \%$.

\section{KESIMPULAN}

Pengetahuan dan sikap seluruh tenaga pengolah makanan masuk dalam kategori baik karena telah diterapkan ISO 9001:2015. Begitu pula dengan penerapan personal hygiene sebelum dan sesudah ISO 9001:2015 menunjukkan bahwa seluruh tenaga pengolah makanan menerapkan personal hygiene dengan baik.

\section{SARAN}

Petugas pengolah makanan di Instalasi Gizi Badan Rumah Sakit Umum Tabanan diharapkan terus mempertahankan pengetahuan, sikap dan penerapan personal hygiene yang baik dalam mengolah makanan; meningkatkan pengawasan terhadap penerapan personal hygiene agar tenaga pengolah makanan tetap menerapkannya dengan baik dan konsisten dan tenaga pengolah makanan yang terluka menutup luka dengan plester kedap air selama mengolah makanan.

\section{DAFTAR PUSTAKA}

Andhini W, Dwi Mustika. 2015. Penerapan Hygiene dan Sanitasi di Instalasi Gizi Rumah Sakit Umum Pusat (RSUP) Dr. M. Djamil Padang. Hal : 6-9.

Augustin, Elfira. 2014. Gambaran Pengetahuan, Sikap dan Tindakan Hygiene Sanitasi Pedagang Makanan Jajanan di Sekolah Dasar Cipinang Besar Utara Kotamadya Jakarta Timur. Skripsi. 
Azwar, S. 2011. Sikap Manusia : Teori dan Pengukurannya. Pustaka Pelajar : Jakarta.

Budiman, Riyanto, A. 2013. Kapita Selekta Kuesioner Pengetahuan dan Sikap dalam Penelitian Kesehatan. Salemba Medika : Jakarta.

Budiyono, dkk. 2009. Tingkat Pengetahuan dan Praktik Penjamah Makanan Tentang Hygiene dan Sanitasi Makanan Pada Warung Makan di Tembalang Kota Semarang Tahun 2008. Jurnal Promosi Kesehatan Indonesia, Vol 4 N0 1. Hal : 53-57.

Chantika, Iqdhana, dkk. 2016. Hygiene Penjamah dan Sanitasi Pengelolaan Makanan di Instalasi Gizi Rumah Sakit Umum Daerah Gambiran Kota Kediri. Jurnal Preventia, Vol 1 No 1. Hal : 7-8.

Depkes RI, 2001. Keputusan Menteri Kesehatan Republik Indonesia Nomor 1216/Menkes/SK/XI/2001 tentang Pedoman Pemberantasan Penyakit Diare.

Depkes RI. 2004. Higiene Sanitasi Makanan dan Minuman. Dirjen PPL dan PM : Jakarta.

Depkes RI. 2006. Pedoman Sanitasi Rumah Sakit di Indonesia. Dirjen PPL dan PM : Jakarta.

Erfandi. 2009. Pengetahuan dan Faktor-Faktor Yang Mempengruhi. http:www.forbetterhealth.wordpress.com

Fathonah, Siti. 2005. Higiene dan Sanitasi Makanan. Unnes Press : Semarang.

Fatmawati, S. Ali, R. dan Ema, H. 2013. Perilaku Higiene Pengolah Makanan Berdasarkan Pengetahuan tentang Higiene Mengolah Makanan Dalam Penyelenggaraan Makanan di Pusat Pendidikan Dan Latihan Olahraga Pelajar Jawa Tengah. Jurnal Gizi Universitas Muhamadiyah Semarang 2 (2). Hal : 30-38.

Fajriyati, Chintya Yusrina. 2016. Gambaran Tingkat Pengetahuan dan Perilaku Higiene Sanitasi Pengolah Makanan di Rumah Sakit Orthopedi Prof. Dr. R. Soeharso Surakarta. Jurnal Gizi Universitas Muhammadiyah Surakarta. Hal : 4-6

Handoko, dalam skripsi Irsyadi, Budi. 2015. Hubungan Masa Kerja Dengan Tingkat Kecemasan Perawat di Ruang Akut Rumah Sakit Jiwa Daerah Surakarta. Hal : 10.

Kementrian Kesehatan RI. 2013. Pedoman PGRS Pelayanan Gizi Rumah Sakit.

Notoatmojo, S. 2003. Pendidikan dan Perilaku Kesehatan. PT Rineka Cipta : Jakarta.

Notoatmojo, S. 2007. Promosi Kesehatan dan Ilmu Perilaku. PT Rineka Cipta : Jakarta.

Notoatmojo, S. 2012. Promosi Kesehatan dan Perilaku Kesehatan. PT Rineka Cipta : Jakarta.

Pasanda, Amalia. 2016. Perbedaan Pengetahuan, Sikap dan Perilaku Penjamah Makanan Sesudah Diberikan Penyuluhan Personal Hygiene di Hotel Patra Jasa Semarang. Skripsi.

Purnawijayanti, H. 2001. Sanitasi, Higiene dan Keselamatan Kerja dalam Pengolahan Makanan. Kanisius : Yogyakarta.

Syahrizal. 2017. Hygiene Sanitasi Penjamah Makanan Terhadap Kandungan Escherichia Coli di Peralatan Makan Pada Warung Makan. Jurnal Action, Vol 2 No 2. Hal : 132-133.

Tarwoto dan Wartonah. 2004. Kebutuhan Dasar Manusia dan Proses Keperawatan. Salemba Medika : Jakarta.

Undang-Undang Nomor 13 Tahun 2003 Tentang Ketenagakerjaan. 
Widyawati, Ayu. 2018. Gambaran Hygiene Penjamah Makan Siang di Bagian Pengolahan Makanan (Lauk Hewani) di Rumah Sakit Umum Daerah Klungkung. Tugas Akhir Jurusan Gizi Poltekkes Kemenkes Mataram, Mataram.

Wulandari, Melii. 2011. Gambaran Higiene dan Sanitasi Penjamah Makanan Di Rumah Sakit Haji Jakarta. Yusuf, Syamsu. 2006. Program Bimbingan dan Konseling di Sekolah. Pustaka Bani Quraisy : Bandung. 